\title{
Menneskers og dyrs helse er knyttet sammen
}

\author{
Zoonotiske infeksjoner er i dag ansett for å være en betydningsfull og økende trussel mot folkehelsen globalt. \\ For å oppnå optimal helse for mennesker og dyr trengs et globalt samarbeid mellom human- og veterinær- \\ medisin.
}

Birgitte Sundt Granberg

Leon Cantas

leon.cantas@nvh.no

Zoonotiske infeksjoner er infeksjoner som kan smitte naturlig mellom virveldyr og mennesker. Smitten kan overføres direkte fra et individ til et annet, eller indirekte via forurenset vann, forurensede matvarer eller gjenstander, eller via vektorer som mygg og flått. Infeksjonene kan være forårsaket av virus, bakterier, rickettsier, sopp, parasitter og prioner. Infiserte dyr og mennesker kan bli syke eller være friske smittebærere (1). Omtrent $75 \%$ av alle nyoppdagede infeksiøse sykdommer som affiserer mennesker er sykdommer av animalsk opprinnelse, og ca. $60 \%$ av smittsomme sykdommer hos mennesker skyldes zoonotiske patogener (2). Det er anslått at zoonotiske infeksjoner forårsaker ca. en milliard tilfeller av sykdom hos mennesker og millioner av dødsfall hvert år (2). I tillegg medfører de store økonomiske, handelsmessige, sosiale og politiske konsekvenser. Disse infeksjonene må forebygges og bekjempes både på lokalt og på globalt nivå.

\section{$\emptyset$ kende problem}

Faren for zoonotiske infeksjoner begrenser seg ikke bare til lavinntektsland. Vår tids flyt av varer og mennesker innenfor og over landegrenser gir patogener av alle slag muligheten til å spre og formere seg verden rundt (2). De siste 30 årene har spesielt matbårne infeksjonssykdommer blitt et økende helseproblem. Dette er et resultat av at internasjonal handel med mat, husdyr og dyrefôr øker, samtidig som husdyrproduksjon, matproduksjon og foredling industrialiseres og sentraliseres (3). Den kraftige økningen av infeksjoner med Salmonella Enteritidis og enterohemoragisk Escherichia coli O157: H7 (4) illustrerer problemet.

En økende forekomst av antibiotikaresistens blant flere av bakteriestammene kan også forklare fremveksten av bakterielle zoonoser. Et eksempel på dette er multiresistente Salmonella Typhimurium, som er motstandsdyktige mot minst fem antimikrobielle stoffer (4).
Mange «nye» zoonoser dukker opp som et resultat av at mennesker og husdyr kommer i tettere og hyppigere kontakt med ville dyr som er reservoar for potensielt zoonotiske patogener. Avskoging og endring i jordbrukspraksis førte eksempelvis til et sykdomsutbrudd forårsaket av Nipahvirus i Malaysia i 1998-99, da gris ble eksponert for fruktflaggermus som var subklinisk infisert med viruset. Viruset spredte seg raskt gjennom landets grisepopulasjon. Mennesker som var i direkte kontakt med grisen ble smittet av viruset, som kunne gi en ofte fatal encefalitt (5). Innførsel og handel med eksotiske kjæledyr kan øke risikoen for å oppleve fremtidige utbrudd av zoonotiske sykdommer. Importerte dyr kan bære patogener og overføre dem til mennesker eller innfødte dyr. Reptilassosiert salmonellose er en av de hyppigst forekommende zoonotiske infeksjonene (6).

Klimaendringer kan utvide rekkevidden av infeksiøse agenser, særlig gjennom vektorer. Insekter koloniserer nye områder som inntil for få år siden var for kjølige for arten. I de siste ti år har insidensen av den flåttbårne infeksjonen Lyme-borreliose økt til det dobbelte i Norge (7).

\section{Overvåking på tvers av fagfelter}

Sammenliknet med sykdommer som kun involverer mennesker, kan ikke zoonoser effektivt kontrolleres eller studeres uten en forståelse av infeksjonsdynamikken i dyrereservoarene (8). Den mest effektive og økonomiske løsningen for å bekjempe zoonotiske patogener er å overvåke og kontrollere infeksjonene i dyrereservoarene (9). Samtidige overvåkingssystemer for mennesker er nødvendig for å identifisere de tiltak som må iverksettes for å unngå sykdom (9). Dette understreker behovet for samarbeid på tvers av fagfelter (10). Overvåkingen kan utøves av ulike organisasjoner internasjonalt, nasjonalt, regionalt og lokalt, og kan være passiv (baseres på informasjon som allerede er samlet) eller aktiv (gå ut og søke informasjon). Hvert system har sine styrker og svakheter. Ofte er mer enn ett overvåkingssystem nødvendig for å oppnå full forståelse av en problemstilling (11).

\section{Overvåking av zoonoser i dyr}

Mattilsynet i Norge gjennomfører hvert år ulike overvåkings- og kartleggingsprogrammer for å forebygge tilførsel av, redusere forekomsten av eller fjerne fremmedstoff, smittestoff eller gifter som finnes i mat, drikke eller i levende dyr. I de fleste overvåkingsprogrammene blir det tatt prøver systematisk over en lengre periode. Zoonosesenteret ved Veterinærinstituttet samler, analyserer og presenterer epidemiologiske data for zoonoser og zoonotiske agenser. Dette danner et grunnlag for å forebygge eventuell smittespredning gjennom fôr, mat, dyr og dyreprodukter som ikke er mat.

Hvert år blir en zoonoserapport utarbeidet av Veterinærinstituttet i samarbeid med Nasjonalt folkehelseinstitutt, Mattilsynet, og Nasjonalt institutt for ernæringsog sjømatforskning, og levert elektronisk til EU-kommisjonen i henhold til et EUdirektiv (1). Direktivets formål er å sørge for at forekomsten av zoonoser og antimikrobiell resistens hos bakterier blir tilstrekkelig overvåket av medlemslandene, og at utbrudd av matbåren sykdom etterfølges av grundige epidemiologiske undersøkelser. Informasjonen som samles inn brukes til å vurdere aktuelle utbruddskilder og -trender.

\section{Overvåking av zoonoser hos mennesker}

Folkehelseinstituttet er ansvarlig for det norske Meldingssystem for smittsomme sykdommer (MSIS). Leger og laboratorier er forpliktet til å melde mistenkte og bekreftede tilfeller av flere spesifiserte infeksjonssykdommer til MSIS. Folkehelseinstituttet deltar i EUs og WHOs overvåking av smittsomme sykdommer (12). Forekomsten av noen viktige zoonoser som overvåkes i Norge i dag er vist i tabell 1 under.

I beste fall gir overvåkingssystemer et estimat av trender, og ikke et nøyaktig mål på prevalens eller insidens. Laboratoriebekreftede tilfeller representerer bare toppen av isfjellet (12), da mange pasienter med mildere sykdomsforløp ikke oppsøker lege eller prøve for laboratorieundersøkelse ikke blir tatt. Samtidig er ethvert overvåkings- 


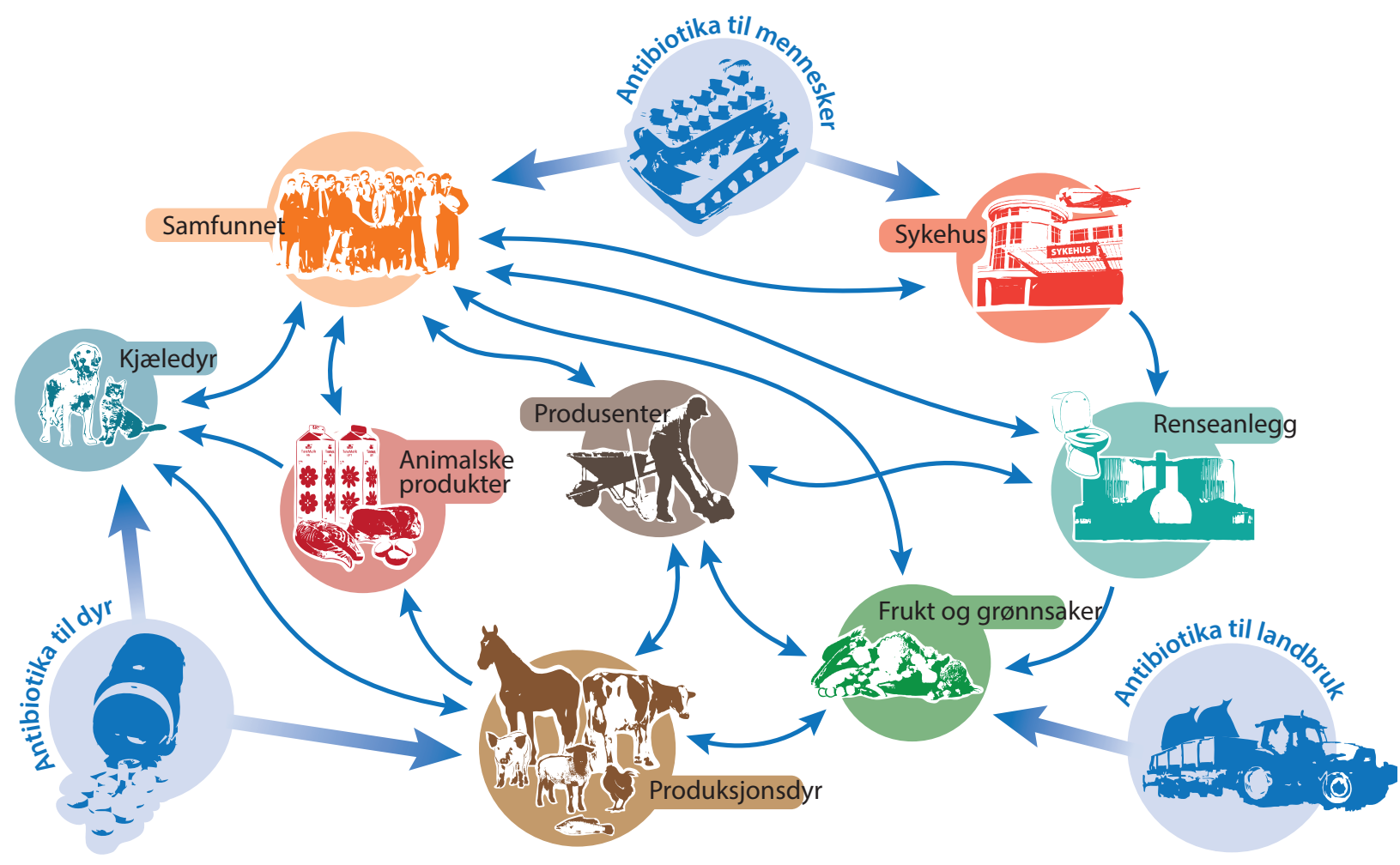

Spredningsmønstre for infeksjoner mellom mennesker, dyr og miljø. Antibiotikaresistente mikrober og resistensgener spres etter samme mønster. Omtegnet av lllumedic med tillatelse fra L. Cantas, 2013

system begrenset av tilgjengelige fasiliteter, som laboratorieutstyr og mikrobiologiske metoder (11).

Overvåkingssystemer, både i mennesker og dyr, må være i stand til å fange opp både kjente og nye infeksjoner. Det må være konstant årvåkenhet på nasjonalt og internasjonalt nivå, og informasjonsutveksling mellom land. Tilgjengelige laboratoriemetoder må revideres fortløpende for å sikre at følsomheten er tilstrekkelig til å oppdage nye patogener (11).

\section{Verdensomspennende strategi}

Et nytt initiativ, som har fătt navnet «One Health», ønsker å bevisstgjøre oss på hvordan vi kan beskytte folkehelsen gjennom å forebygge og kontrollere patogener på dyrenivå i krysningspunktet mellom mennesker, dyr og miljø (9). Det er en verdensomspennende strategi hvor målet er å oppnå optimal helse for mennesker og dyr ved å fremme globalt samarbeid mellom human- og veterinærmedisin (13). Det er blitt mulig å sette «One Health»-visjonen ut i praksis gjennom en felles avtale mellom Verdens helseorganisasjon (WHO), FNs organisasjon for ernæring, landbruk, skogbruk og fiskeri (FAO) og Verdens dyrehelseorganisasjon (OIE). De tre organisasjonene har publisert en felles beskrivelse hvor de klargjør gjensidig ansvar og mål innen dette feltet. De har besluttet å velge følgende prioriterte temaer for sine felles tiltak: rabies, som fortsatt dreper nesten 70000 mennesker hvert år, zoonotiske influensavirus og resistens overfor antimikrobielle midler (9). For at denne visjonen skal kunne lykkes, er det viktig med tilgang til veterinærenes kunnskaper og erfaringer.

\section{Veterinærens rolle}

Vi bør ta lærdom av akvanæringens suksesshistorie. Oppdrettsnæringen har redusert antibiotikaforbruket med $99 \%$ over 30 år, samtidig som produksjonen har økt med $90 \%$. Dette tilskrives rask diagnostisering, innsamling av informasjon til utvikling av databank, innføring av vaksineringsprogram og søkelys på fiskens immunsystem (14). Det norske landbruket nyter stor internasjonal anseelse på grunn av effektivt smittevern, restriktiv legemiddellovgivning, individuelle helsekort og medisinrapportering. Bedre tilgang på laboratorietjenester i produksjonsdistriktene vil bedre førstelinjediagnostikken og samtidig åpne for mer forebyggende arbeid og bestandsrådgivning.

Våre kjæledyr, hest inkludert, utgjør i dag det raskest voksende pasientsegmentet innen veterinæryrket. Disse dyrenes infeksjoner resulterer $i$ at en betydelig, og stadig økende andel av antibiotikaforbruket går til kjæledyr og hest (36\% økning over 20 år) (14).

Dyrene betraktes som familiemedlemmer og har svært tett kontakt med mennesker, spesielt barn. Dette danner et felles mikrobium for overføring av antibiotikaresistente bakteriestammer og mobile resistenselementer mellom dyr og mennesker $(15,16)$.
Veterinærens rolle i utviklingen av antibiotikaresistens hos bakterier i miljø, mennesker, dyr og næringsmidler er åpenbar siden utskrivning av antibiotika til dyr i Norge er tillagt veterinærene og fiskehelsekandidatene. Mer presis diagnostisering og god kunnskap om antibiotikavalg vil kunne bidra betydelig til å redusere utviklingen av antibiotikaresistens hos dyrepatogene bakterier i Norge, og sekundært hos humanpatogene bakterier. Økt infeksjonsmedisinsk kompetanse hos norske veterinærer vil bidra til at vi vil ha effektive antibiotika tilgjengelig for dyr og mennesker i fremtiden.

\section{Samlet innsats}

Overvåking av zoonotiske infeksjoner er viktig for å beskytte både dyrs og menneskers helse. Overvåking i dyrereservoarene gir mulighet for målrettede og effektive tiltak som kan gjennomføres før sykdommene overføres til mennesker. Fremgang i forebygging og kontroll av smittsomme sykdommer krever en mer rettet innsats og søkelys på det komplekse samspillet mellom menneskers helse, dyrehelse og miljø. I Norge viser årlige rapporter at norske strategier for kontroll av zoonoser og utvikling av generell antibiotikaresistens hittil har vært vellykkede både i husdyrholdet og i helsevesenet. Faren for økende antibiotikaresistens er imidlertid til stede på grunn av økt antibiotikabruk og import av resistente bakterier fra andre land. Det er 
Tabell 1 Forekomsten av noen viktige zoonoser som blir overvåket i Norge (12). Gjengitt med tillatelse fra Folkehelseinstituttet

\begin{tabular}{lcl}
\hline Sykdom & $2011(\mathrm{~N})$ & Bemerkning \\
Campylobakteriose & 3005 & Ca. $50 \%$ smittet i utlandet \\
Salmonellose & 1290 & Ca. $80 \%$ smittet i utlandet \\
EHEC-infeksjon ${ }^{1}$ & 47 & $30-80 \%$ smittet i utlandet \\
Yersiniose & 60 & $20-50 \%$ smittet i utlandet \\
Listeriose & 21 & $0-7$ dødsfall per år \\
Ekinokokkose & 2 & Smittet i utlandet \\
Brucellose & 2 & Smittet i utlandet \\
Storfetuberkulose & 2 & Positive født i utlandet \\
Trikinose & 0 & - \\
Rabies & 0 & - \\
\hline
\end{tabular}

${ }^{1}$ Infeksjon med enterohemoragisk Escherichia coli

derfor nødvendig med fortsatt aktiv innsats for å sikre at vi også i fremtiden kan gi effektiv antibiotikabehandling. Med gode diagnostiseringsverktøy, effektive overvåkingsprogrammer og kunnskap som sikrer riktig terapivalg, må veterinærer og leger stå samlet i kampen mot zoonotiske infeksjonssykdommer.

Vi takker Øyvind Berven og Henning Sørum for gjennomlesning og kommentarer til artikkelen.

\section{Birgitte Sundt Granberg (f. 1970}

er seniorinspektør/veterinær ved Mattilsynet, Seksjon for primærproduksjon og kjøttkontroll Distriktskontoret for Romerike, er veterinær ved Vet2Pets.no og studerer til MSc i Veterinary Epidemiology and Public Health ved The Royal Veterinary College, University of London, international programmes.

Forfatter har fylt ut ICMJE-skjemaet og oppgir ingen interessekonflikter.

\section{Leon Cantas (f. 1987)}

er doktorgradsstipendiat ved Norges veterinærhøgskole, daglig leder (CEO)/veterinær og dyrhelsekonsulent ved MegaVet.no.

Forfatter har fylt ut ICMJE-skjemaet og oppgir ingen interessekonflikter.

\section{Litteratur}

1. Hofshagen M. Heier BT. Hauge K. Zoonoserapporten 2011. Oslo: Veterinærinstituttet, 2012

2. Kilpatrick AM, Randolph SE. Drivers, dynamics, and control of emerging vector-borne zoonotic diseases. Lancet 2012; 380: 1946-55.

3. Kapperud G. Salmonella. I: Granum PE, red. Matforgiftning, næringsmiddelbårne infeksjoner og intoksikasjoner. 3.utg. Kristiansand: Høyskoleforlaget, 2007: 118-35.

4. Blancou J, Chomel B, Beletto A. Emerging or reemerging bacterial zoonoses: factors of emerge, surveillance and control. Vet Res 2005; 36 : 507-22. www.ncbi.nlm.nih.gov/pubmed/15845237 (26.4.2012)

5. Rhyan JC, Spraker TR. Emergence of diseases from wildlife reservoirs. Vet Pathol 2010; 47: 34-9. http://intl-vet.sagepub.com/content/47/1/34.full (11.4.2013)

6. Chomel BB, Belotto A, Meslin FX. Wildlife, exotic pets, and emerging zoonoses. Emerg Infect Dis 2007; 13: 6-11.

7. Eliassen KE. Fagartikkel: Lyme borreliose - Nordens «tropesykdom». Bioingeniøren 2011; nr. 2. www.nito.no/Fagmiljoer/Bioingeniorfagliginstitutt/Bioingenioren/Alle-Bioingeniorene/ Bioingenioren-2011/Bioingenioren-4-2011/ Fagartikkel-Lyme-borreliose--Nordenstropesykdom-/ (13.3.2013).

8. Leslie MJ, McQuiston JH. 2007. Surveillance for zoonotic diseases. I: M'ikanatha NM, Lynfield R, Van Beneden CA et al., red. Infectious disease surveillance. Oxford: Blackwell, 2007

9. OIE. «One Health». www oie.int/for-the-media/ editorials/detail/article/one-health/ (16.2.2013)

10. OIE. One world, one health. www.oie.int/for-themedia/editorials/detail/article/one-world-onehealth/ (9.2.2013)

11. Veterinary Public Health. Module 1 «Surveillance of Zoonotic disease». London: Royal Veterinary College, University of London, 2007.

12. Nasjonalt folkehelseinstitutt. Statistikk og overvåking - Smittsomme sykdommer. www.fhi.no/eway/ default.aspx?pid=233\&MainArea_5661=5631:0: 15,3787:1:0:0:0:0 http://www.fhi.no/helseregistre/ msis/statistikk (12.2.2013).

13. One Health Initiative. About the One health Initiative www.onehealthinitiative.com/index.php (16.2.2013)

14. NORM/NORM-VET 2010. Usage of antimicrobial agents and occurance of antimicrobial resistance in Norway. Troms $\varnothing / 0$ slo: Veterinærinstituttet, 2011. www.vetinst.no/eng/Publications/NormNorm-Vet-Report/Norm-Norm-Vet-rapporten2010 (11.4.2013).

15. Cantas L, Midtlyng PJ, Sørum H. Impact of antibiotic treatments on the expression of the R plasmid tra genes and on the host innate immune activity during pRAS1 bearing Aeromonas hydrophila infection in zebrafish (Danio rerio). BMC Microbiol 2012; 12: 37. www.biomedcentral.com/1471-2180/ 12/37 (11.4.2013).

16. Cantas $L$, Shah $S Q$, Cavaco LM et al. A brief multi-disciplinary review on antimicrobial resistance in medicine and its linkage to the global environmental microbiota. Front Microbiol 2013; 4: 96. www.frontiersin.org/

Antimicrobials,_Resistance_and_Chemotherapy/ 10.3389/fmicb.2013.00096/abstract (11.4.2013).

Mottatt 8.2. 2013, første revisjon innsendt 19.2. 2013, godkjent 25.3. 2013. Medisinsk redaktør Hanne Støre Valeur. 